\title{
Upaya Peningkatan Kemampuan Pemecahan Masalah Matematis Siswa dengan Pendidikan Matematika Realistik Indonesia
}

\author{
Reni Wahyuni \\ Universitas Islam Riau \\ e-mail: reni_whyn@yahoo.com
}

\begin{abstract}
ABSTRAK
Penelitian ini merupakan suatu penelitian tindakan kelas yang berkolaborasi dengan guru matematika di sekolah sehingga tujuan penelitian adalah untuk memperbaiki proses pembelajaran sehingga memiliki dampak pada upaya peningkatan kemampuan pemecahan masalah matematis siswa kelas VIIc MTs Diniyah Puteri Pekanbaru. Secara teoritis dipilihlah suatu proses pembelajaran yang sesuai dengan masalah di kelas tersebut adalah Pendidikan Matematika Realistik Indonesia (PMRI) sebagai penerapannya. Pada penelitian ini didesain dengan menerapkan pendekatan PMRI berdasarkan karakteristik PMRI. Penelitian ini terdiri dari dua siklus untuk memperbaiki proses pembelajaran dan melihat kemampuan pemecahan masalah matematis siswa. Berdasarkan hasil analisis data dengan menggunakan lembar pengamatan pada siklus 1 dan siklus 2 maka terjadi perbaikan proses pembelajaran yang terlihat dari kegiatan aktifan siswa dalam belajar, bekerja sama, rasa ingin tahu , diskusi dan memberikan respon pada presentasi kelompok. Selanjutnya jika ditinjau tes kemampuan pemecahan masalah matematis siswa maka diperoleh rata-rata 63.15 dengan ketuntasan sebanyak 11 siswa sedangkan pada siklus II memperoleh rata-rata 70,70 dengan ketuntasan sebanyak 15 siswa. Secara klasikal terjadi peningkatan ketuntasan sebanyak 4 orang dari siklus 1 ke siklus 2 maka dapat disimpulkan bahwa pendekatan PMRI dapat memperbaiki proses pembelajaran dan meningkatkan kemampuan pemecahan masalah matematis siswa kelas VIIc MTs Diniyah Puteri Pekanbaru.
\end{abstract}

Kata kunci: PMRI, PTK, kemampuan pemecahan masalah matematis

\begin{abstract}
This research is a classroom action research in collaboration with schools mathematics teachers so that the purpose of research is to improve the learning process so as to have an impact on improving the students' mathematical problem solving ability VIIc grade MTs Diniyah Puteri Pekanbaru. Theoretically chosen a learning process that is appropriate to the problem in the class is Indonesian Realistic Mathematics Education (PMRI) as its application. In this study was designed to implement an approach based on the characteristics PMRI. The study consisted of two cycles to improve the learning process and see the students' mathematical problem solving ability. Based on the analysis of data using observation sheet in cycle 1 and cycle 2, the improvements were visible learning process of the students in learning activities, working together, curiosity, discussion and responses to the group presentation. Furthermore, if the review test students' mathematical problem solving ability then gained an average of 63.15 with a mastery of as many as 11 students while in the second cycle obtain an average of 70.70 with a mastery of as many as 15 students. Traditionally an increase of completeness of 4 people from cycle 1 to cycle 2 it could be concluded that PMRI approach could improve the learning process and improve students' mathematical problem solving ability class VIIc MTs Diniyah Puteri Pekanbaru.
\end{abstract}

Keywords: PMRI, PTK, mathematical problem solving skill

\section{PENDAHULUAN}

Matematika merupakan suatu pelajaran yang sudah dimulai dari tahun 1973 dengan nama yaitu "berhitung". Namun dengan adanya pergantian kurikulum maka berganti jugalah nama pelajaran tersebut dengan lebih kenal sekarang ini yaitu mata pelajaran matematika. Pembelajaran matematika merupakan suatu pembelajaran yang bertujuan untuk mengembangkan 
kemampuan berhitung, mengukur dan menggunakan rumus matematika yang diperlukan dalam kehidupan sehari-hari. Sejalan dengan fungsi pembelajaran tersebut maka diperlukanlah suatu pembelajaran yang dapat melatih daya pikir dan nalar, menyelesaikan permasalahan dan mengkomunikasikan gagasan serta pembentukan keterampilan matematika.

Namun pada kenyataannya matematika sering kali dianggap siswa sebagai momok yang menakutkan sehingga siswa merasa tidak mau mempelajari lebih jauh lagi tentang matematika. Salah satu kenyataan di lapangan adalah di sekolah MTs Diniyah Puteri Pekanbaru. Berdasarkan tinjauan awal peneliti di sekolah tersebut menunjukkan bahwa siswa-siswa di kelas VIIc mempunyai kesulitan dalam mempelajari pembelajaran matematika. Untuk mengetahui kemampuan pemecahan masalah matematis dilakukan tes awal kepada kelas VIIc sehingga diperoleh bahwa rata-rata kemampuan pemecahan masalah matematis siswa adalah 58,15. Berdasarkan hasil tes awal kemampuan pemecahan masalah matematis siswa maka dapat disimpulkan masih tergolong rendah. Ditinjau dari pengamatan di kelas, salah satu faktor permasalahan yang terjadi di kelas VIIc adalah kesulitan dalam mempelajari soal-soal yang berbentuk cerita. Dalam proses pembelajaran siswa biasanya dihadapkan langsung berupa rumus-rumus atau bentuk formal dari matematika sehingga siswa sering menghafal rumus daripada melakukan suatu percobaan pemecahan masalah dari soal cerita yang diberikan. Menurut Sudjana (2008) mengemukakan bahwa keberhasilan siswa tidak terlepas dari kualitas proses pembelajaran yang dilakukan guru, kualitas proses pembelajaran mempunyai hubungan berbanding lurus dengan hasil belajar

Dalam standar kurikulum yang ditetapkan sekolah, maka pencapaian siswa dalam KKM merupakan suatu tolak ukur dalam menentukan keberhasilan belajar siswa. Namun, sebenarnya keberhasilan siswa tidak terlepas dari proses pembelajaran yang dilakukan guru. Sehingga dapat dikatakan bahwa kualitas proses pembelajaran mempunyai hubungan berbanding lurus dengan hasil belajar. Untuk mengatasi permasalahan-permasalahan tersebut, diperlukan adanya upaya guru dalam menggunakan model/pendekatan pembelajaran dan sarana pembelajaran yang dapat memenuhi tuntutan kebutuhan siswa dalam belajar sesuai dengan tahap perkembangan pengetahuannya. Guru dituntut untuk menggunakan metode yang bervariasi dan tidak hanya terfokus pada metode ceramah tetapi juga menggunakan metode-metode pembelajaran yang lebih menekankan pada pembelajaran yang aktif, kreatif, efektif dan menyenangkan. Selain hal tersebut, guru dituntut untuk mampu menciptakan suatu permasalahan matematika yang ada disekitar pengetahuan siswa.

Salah satu pendekatan pembelajaran inovasi yang dapat digunakan dalam perbaikan pembelajaran matematika adalah pendekatan Pendidikan Matematika Realistik Indonesia (PMRI). PMRI merupakan adaptasi dari teori RME dari belanda. Sedangkan RME banyak diwarnai oleh pandangan Freudenthal tentang matematika. Dua pandangan penting beliau adalah matematika harus dihubungkan dengan realitas dan matematika sebagai aktivitas manusia (Zulkardi, 2001) pertama, matematika harus dekat terhadap siswa dan harus dikaitkan dengan situasi kehidupan sehari-hari. Kedua, matematika sebagai aktivitas manusia, sehingga siswa harus diberi kesempatan untuk belajar melakukan aktivitas matematisasi pada semua topik dalam matematika.

Menurut Freudhental (dalam Hadi, 2005) "RME menggabungkan pandangan tentang apa itu matematika, bagaimana siswa belajar matematika, dan bagaimana matematika harus diajarkan". Menurut Gravemeijer (1994) menyatakan 
"Mathematical activity as an activity of solving problems, looking for problems and organizing a subject matter-whether mathematical matter or data from reality" yang artinya "kegiatan matematika sebagai suatu kegiatan pemecahan masalah, mencari masalah dan pengorganisasian materi-materi pelajaran matematika apakah atau data dari kenyataan".

Pada teori RME yang diberikan menyarankan bahwa dari pada mengajar dari level formal, lebih baik, siswa diajari dari level informal dimana siswa mengenalnya di kehidupan sehari-hari. Van den HeuvelPanhuizen dan Drijvers (2014) menjelaskan bahwa RME dikenal dengan "pendidikan matematika dunia nyata". Sehingga kadang menimbulkan interpretasi yang membingungkan dalam penggunaan kata realistic tersebut. Alasan reformasi pendidikan matematika Belanda disebut "realistic" adalah bukan hanya karena hubungannya dengan dunia nyata, tetapi terkait dengan penekanan bahwa dalam RME siswa diberikan situasi-situasi masalah yang bisa mereka bayangkan. Van den HeuvelPanhuizen dan Drijvers pun memperjelas bahwa untuk masalah yang disajikan kepada siswa, konteks yang dipilih tidak harus dari dunia nyata. Dunia fantasi bahkan dunia matematika formal dapat memberikan konteks yang sesuai untuk suatu masalah, selama mereka nyata dalam pikiran siswa.

Oleh karena itu, peneliti berkolaborasi dengan guru bidang studi pendidikan matematika MTs Diniyah Puteri Pekanbaru melakukan upaya perbaikan proses pembelajaran dalam upaya peningkatan kemampuan pemecahan masalah matematis siswa pada materi persamaan dan pertidaksaan linear satu variabel. Oleh karena itu, penelitian ini bertujuan untuk mengetahui perbaikan proses pembelajaran dan meningkatkan kemampuan pemecahan masalah matematis siswa kelas VIIc MTs Diniyah Puteri Pekanbaru dengan materi pokok persamaan dan pertidaksamaan linear satu variabel.

\section{METODE}

Rancangan penelitian yang digunakan dalam penelitian ini adalah Penelitian Tindakan Kelas (PTK) dengan model siklus. PTK yang dimaksudkan adalah sebagai suatu bentuk kajian yang bersifat reflektif dalam perilaku tindakan yang dilakukan untuk meningkatkan tindakan serta memperbaiki kondisi dimana praktik-praktik tindakan tersebut dilakukan. PTK ini merupakan refleksi dari guru sehingga PTK yang dilakukan merupakan kolaborasi antara peneliti dengan guru sekolah di MTs Diniyah Puteri. Mengacu pada model Kemmis \& McTaggart (Arikunto, Suhardjono \& Supardi, 2010) menyatakan bahwa siklus pada PTK berupa siklus yang terdiri dari 4 tahap yaitu: (1) perencanaan (plan); (2) pelaksanaan (action); (3) pengamatan (observation); (4) refleksi (reflection).

Subjek Penelitian adalah siswa kelas VIIc MTs Diniyah Puteri semester genap tahun pelajaran 2024/2015 yang terdiri dari 27 siswa. Kemampuan siswa secara akademik heterogen.

Pengumpulan data yang diperoleh dalam penelitian ini merupakan (1) Lembar pengamatan guru dan siswa; (2) hasil atau strategi penyelesaian kelompok; (3) tes hasil belajar matematika siswa berupa kemampuan pemecahan masalah; (4) lembar wawancara siswa. Lembar pengamatan guru dan siswa digunakan untuk menggali data proses pelaksanaan pembelajaran di dalam kelas. Lembaran hasil atau strategi penyelesaian kelompok siswa merupakan kontribusi siswa dalam memecahkan permasalahan realistik sehingga siswa mengembangkan hasil kerjanya dan mendiskusikannya di dalam kelas untuk mencapai tujuan pembelajaran. Tes hasil belajar adalah hasil kompetensi atau kemampuan siswa dalam memahami materi pembelajaran yang diberikan. Sedangkan untuk lembar wawancara adalah untuk 
menggali data pemahaman siswa tentang materi pembelajaran yang dipelajari. Data yang diperoleh dalam setiap siklus ini penelitian ini dianalisis secara deskriptif kualitatif dengan menggunakan statistik deskriptif. Kegiatan analisis ini dimaksudkan untuk mengolah data pada masing-masing siklus sehingga dapat dideskripsikan bagaimana peningkatan hasil belajar matematika siswa. Cara yang ditempuh untuk menganalisis hasil kerja siswa adalah melihat dan membandingkan skor hasil tes pada masing-masing siklus. Apabila skor hasil kemampuan pemecahan masalah matematis masing-masing siklus mengalami peningkatan dapat dikatakanlah adanya peningkatan dari segi hasil kemampuan pemecahan masalah matematis siswa.

\section{HASIL DAN PEMBAHASAN}

Penelitian ini merupakan PTK dengan dilaksanakan sebanyak dua siklus. Dalam setiap siklusnya terdiri dari tiga kali pertemuan yang dirancang dalam memperbaiki proses pembelajaran dan meningkatkan kemampuan pemecahan masalah matematis siswa. Penerapan yang di dalam kelas menggunakan pendekatan PMRI yang disesuaikan dengan karakteristik siswa. Dalam setiap pertemuan dirancang suatu kontek realistik dengan permasalahan yang sering dihadapi dalam kehidupan sehari-hari siswa.

Untuk mengetahui bagaimana peningkatan kemampuan pemecahan masalah matematis siswa, maka dapat dibuktikan dari ketuntasan siswa dari setiap siklus. Dari setiap siklus yang dilakukan, ketuntasan siswa mengalami meningkatan dari nilai dasar, Ulangan Harian I dan Ulangan Harian II dengan batas KKM adalah 70. Data yang diperoleh mengenai kemampuan pemecahan matematis siswa sebelum tindakan sampai siklus II secara keseluruhan ditunjukkan pada tabel sebagai berikut ini:
Tabel 1. Data Peningkatan Hasil Belajar Matematika Siswa Kelas VIIc MTs Diniyah Puteri Pekanbaru

\begin{tabular}{|l|l|l|l|l|}
\hline No & \multicolumn{1}{|c|}{ Aspek } & $\begin{array}{c}\text { Sebelum } \\
\text { Tindakan }\end{array}$ & Siklus I & $\begin{array}{c}\text { Siklus } \\
\text { II }\end{array}$ \\
\hline 1 & $\begin{array}{l}\text { Siswa yang } \\
\text { mencapai } \\
\text { KKM }\end{array}$ & 6 siswa & $\begin{array}{l}11 \\
\text { siswa }\end{array}$ & $\begin{array}{l}15 \\
\text { siswa }\end{array}$ \\
\hline 2 & $\begin{array}{l}\text { Persentase } \\
\text { siswa yang } \\
\text { mencapai } \\
\text { KKM }\end{array}$ & $22.22 \%$ & $40.74 \%$ & $55.56 \%$ \\
\hline 3 & $\begin{array}{l}\text { Rata-rata } \\
\text { Siswa }\end{array}$ & 58,15 & 63,15 & 70,70 \\
\hline
\end{tabular}

Sumber: Olahan Data Peneliti

Berdasarkan tabel 1 dapat dilihat adanya peningkatan banyaknya siswa yang tuntas. Perubahan tersebut dapat dihitung dengan selisih banyaknya siswa setiap siklus. Pada sebelum tindakan siswa yang tuntas pada kemampuan pemecahan masalah sebanyak 6 siswa sehingga terdapat peningkatan sebanyak 5 siswa yang tuntas pada siklus I. Sedangkan dari siklus I siswa yang meningkat sebanyak 4 orang. Hal ini menunjukkan bahwa dari segi ketuntasan kemampuan pemecahan masalah matematis siswa adanya terdapat peningkatan. Ketuntasan kemampuan pemecahan masalah matematis yang dimaksudkan dalam penelitian ini yaitu ketuntasan belajar siswa dari segi kemampuan pemecahan masalah matematis. Ketuntasan belajar siswa dimaksudkan adalah jika siswa sudah mencapai Kriteria Ketuntasan Minimal (KKM) dengan nilai lebih dari sama dengan 70 maka siswa dikatakan tuntas dan sudah mencapai hasil belajar yang baik. Siswa dikatakan tuntas belajar dalam setiap putaran jika mencapai $\mathrm{KKM}$ dengan nilai $\geq 70$ dari seluruh soal yang diberikan. Nilai siswa yang belum mencapai KKM akan dilakukan pengayaan untuk memberikan pemahaman lagi kepada siswa yang masih di bawah nilai KKM.

Sedangkan untuk rata-rata kelas yang diberikan siswa terdapat perubahan peningkatan dari nilai dasar, siklus I dan siklus II. Siswa memberikan rata-rata pada 
nilai dasar sebanyak 58,15. Jika dibandingkan dengan siklus I yang diperoleh 63,15 maka terdapat perubahan peningkatan sebesar 5 poin sedangkan perubahan pada siklus II terdapat perubahan sebesar 7,55 poin dari siklus I. Hal ini menunjukkan terdapat peningkatan rata-rata siswa untuk kemampuan pemecahan masalah matematis.

Selain kemampuan pemecahan masalah yang ditunjukkan dengan peningkatan, selama kegiatan proses pembelajaran peneliti juga melakukan analisis terhadap sikap kerjasama dan rasa ingin tahu siswa. Pengamatan ini dilakukan karena peneliti menyesuaikan dengan penerapan dan karakteristik PMRI. Peneliti melihat bahwa dengan adanya perubahan sikap kerjasama dan rasa ingin tahu siswa merupakan dampak dari diterapkannnya pembelajaran PMRI dalam di kelas. Hal ini dapat di tunjukkan dalam grafik sebagai berikut ini.

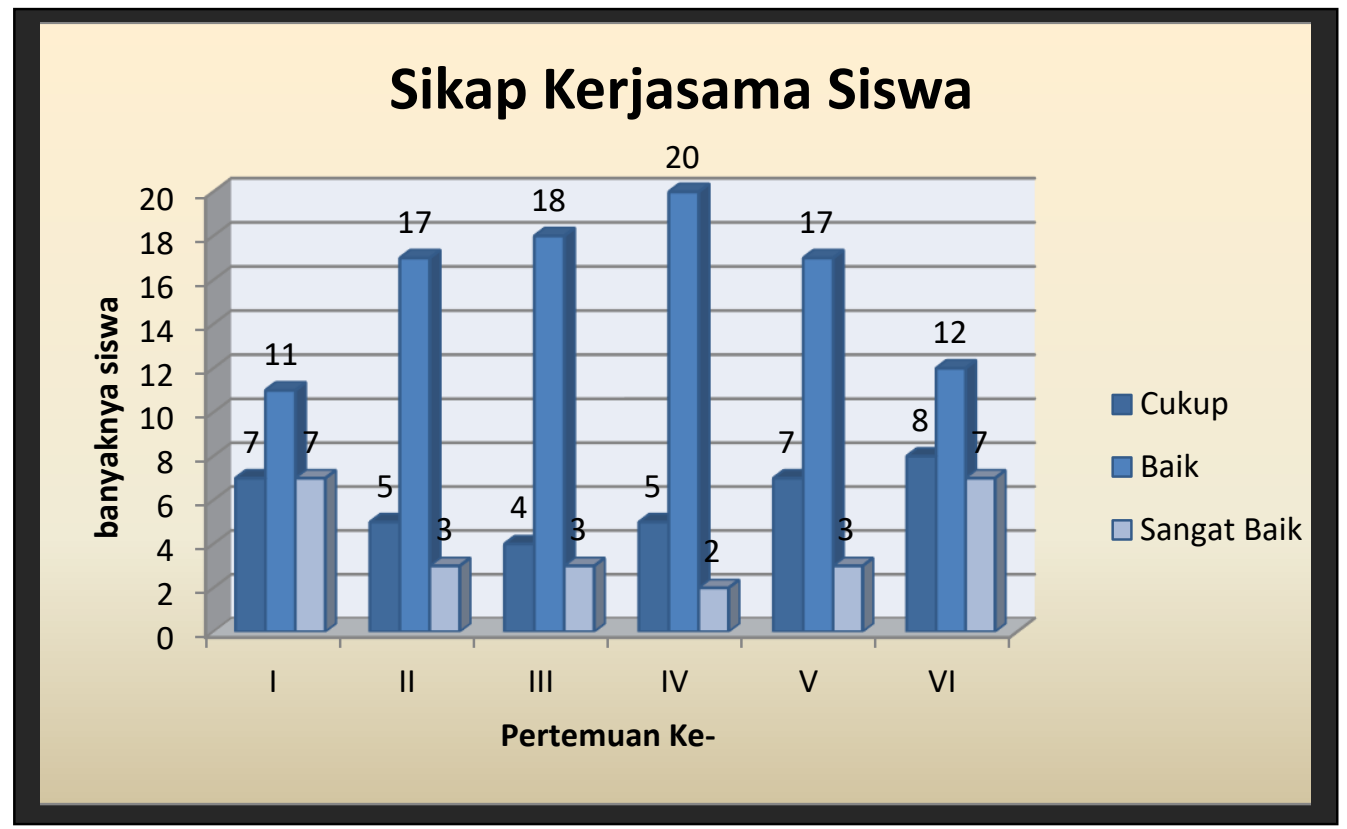

Gambar 1. Grafik Peningkatan Sikap Kerjasama Siswa Kelas VIIc MTs Diniyah Puteri

Berdasarkan gambar grafik 1 yang diberikan dari setiap pertemuan. Diperoleh bahwa adanya perubahan sikap kerjasama siswa dari setiap siklus. Untuk siklus pertama yang dilihat dari pertemuan I, II dan III maka dapat dilihat bahwa adanya peningkatan kerjasama siswa dalam kelompok. Namun pada siklus kedua yang dilihat dari pertemua IV, V dan VI maka terlihat sikap siswa yang mulai menurun. Dari analisis data tersebut, maka peneliti meninjau kembali ke dalam proses pembelajaran yang terjadi. Sikap kerjasama siswa tersebut terjadi perubahan dari siklus I dan II, hal ini dapat dimungkinkan dengan pengaruh pemberian konteks pembelajaran yang diberikan. Pada siklus ke II siswa diarahkan kepada permasalahan yang lebih kompleks dari pada siklus I. Jika pada siklus I dibutuhkan kerjasama dalam menyelesaikan permasalahan permainan maka pada siklus II lebih diarahkan kepada penerapan permasalahan. Ternyata sikap siswa pun menjadi merubah dari sangat baik bekerjasama menjadi dengan baik bekerjasama. 


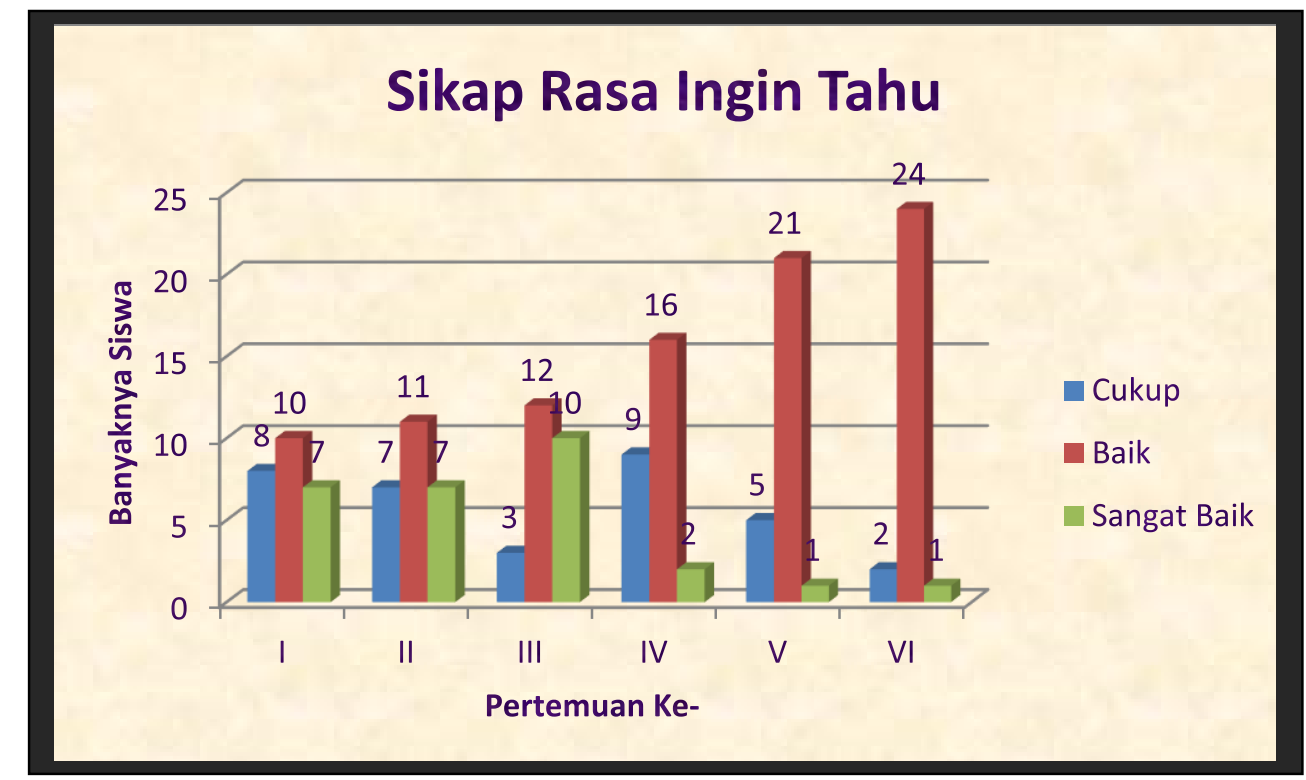

Gambar 2. Grafik Peningkatan Sikap Rasa Ingin tahu Siswa Kelas VIIc MTs Diniyah Puteri

Ditinjau dari sikap rasa ingin tahu siswa, gambar grafik 2 memberikan gambaran bahwa rasa ingin tahu siswa setiap pertemuan baik dari siklus I dan siklus II terdapat peningkatan secara keseluruhan. Hal ini diindikasikan dari data yang diberikan pada setiap pertemuan. Sikap siswa dengan indikator baik pada setiap pertemuan meningkat jumlahnya. Terutama pada pertemuan ke VI, banyak siswa indikator baik sebanyak 24 orang. Hal berarti siswa yang memiliki rasa ingin tahu dalam menyelesaikan permasalahan semakin meningkat setiap pertemuannya.

Kedua aspek pengamatan sikap selama proses pembelajaran memberikan indikasi bahwa penerapan PMRI dalam pembelajaran memberikan dampak selama proses pembelajaran sehingga perubahan-perubahan tersebut merupakan salah satu perbaikan dalam proses pembelajaran. Indikasi yang menunjukkan perbaikan proses pembelajaran dalam dilihat lagi dari aktivitas-aktivitas siswa selama proses pembelajaran dengan diberikan ragam permasalahan dari setiap pertemuan.

Berdasarkan hasil lembar pengamatan yang dilakukan peneliti, pada siklus I dan II menunjukkan bahwa kegiatan pembelajaran mengalami perbaikan baik dari segi guru maupun siswa denga acuan berdasarkan karakteristik RME. Siswa diberikan kesempatan untuk menemukan kembali matematika itu sendiri. Strategi informal yang diberikan siswa menjadikan inspirasi sebagai pendahuluan bentuk informal untuk ke prosedur formal. Siswa diberikan suatu aktivitas atau permasalahan realistik kemudian siswa mencari dan membuat strategi berdasarkan pengetahuannya yang ada. Hasil yang diberikan siswa beragam sehingga diskusi kelompok dan interaktivitas terjadi pada proses pembelajaran ini.

Proses pembelajaran yang menggunakan beragam model atau skema dari matematika maka hal ini merupakan bentuk karakteristik RME yang kedua yaitu the use of the models or bridging by vertical instruments. Siswa dapat mengembangkan atau menciptakan model simbolik secara informal dari permasalahan realistik yang diajukan. 


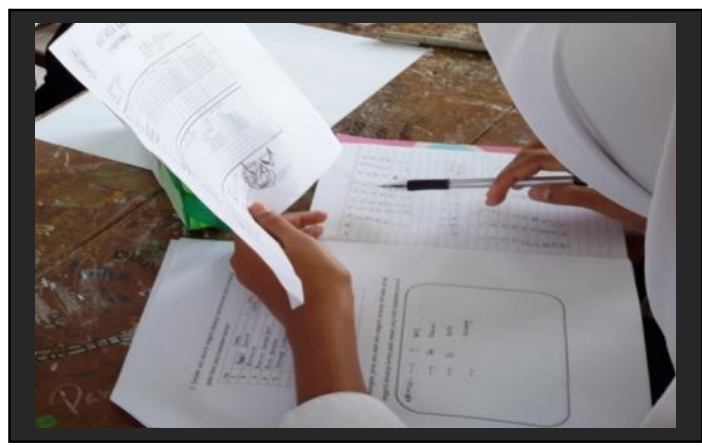

Gambar 3. Strategi siswa dalam menyelesaikan permasalahan realistik

Berdasarkan karakteristik RME yang keempat yaitu the interactive character of the teaching process or interactivity, maka proses pembelajaran sudah berganti dengan guru sebagai fasilitator. Guru membimbing dan menghargai setiap kontribusi yang siswa berikan. Interaksi berupa intervensi, diskusi, memberikan penjelasan, komunikasi dan koperatif saling terjalin pada proses pembelajaran.

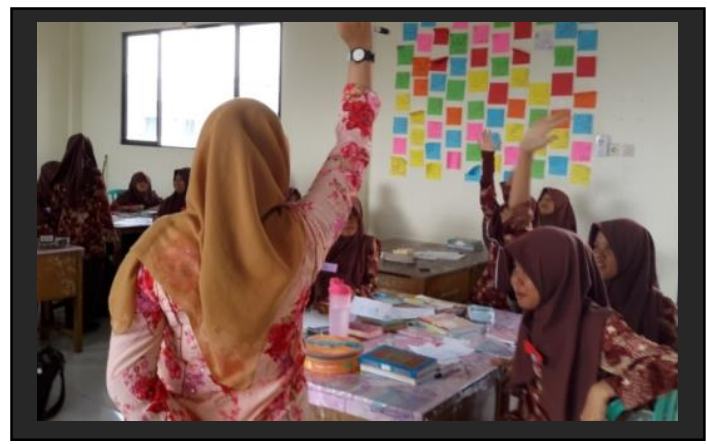

Gambar 3. Antusias siswa untuk mempresentasikan hasil diskusinya

Pada proses pembelajaran yang terjadi siswa terlihat antusias dari setiap arahan yang diberikan guru. Siswa lebih sering berkomunikasi dengan temannya, berdiskusi dan mengintervensi jika jawaban yang diberikan siswa lainnya kurang tepat. Hal ini terjadi perubahan dari pola pembelajaran sehingga suasana pembelajaran jadi menyenangkan.

Keinginan

siswa dalam mempresentasikan hasil jawaban juga antusias. Hal ini terlihat dari gambar 3 bahwa siswa ingin hasil dikusi kelompoknya di pajang di papan tulis dan siswa juga ingin mempresentasikan. Sehingga dapat dilihat dari hasilnya bahwa papan tulis di kelas ditempel dengan semua jawaban siswa yang telah ditulis di kertas. Indikasi ini juga sesuai dengan data yang diberikan bahwa rasa ingin tahu siswa dalam mempresentasikan hasil pekerjaannya dan siswa pun berani mengeluarkan pendapatnya jika ada jawaban siswa lainnya yang berbeda.

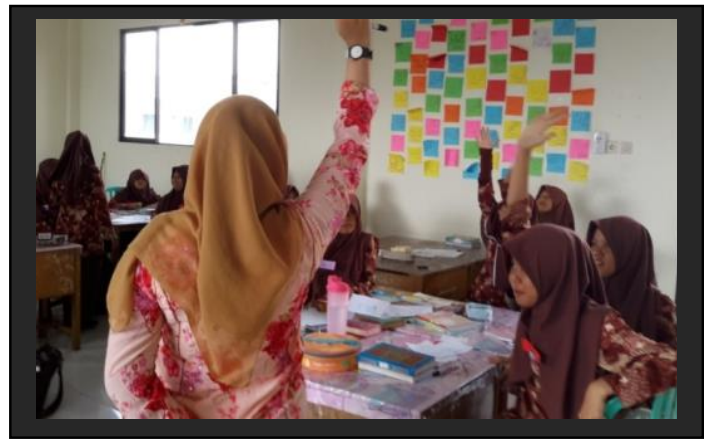

Gambar 4. Siswa semangat menempel poster hasil diskusinya

Temuan penelitian yang diperoleh dari penelitian ini sejalan dengan saran dari penelitian Sugiman dan Kusumah (2010) tentang pendidikan matematika realistic dapat diterapkan sebagai alternative pendekatan pembelajaran guna meningkatkan kemampuan pemecahan masalah matematik siswa SMP/MTs.

\section{PENUTUP \\ Kesimpulan}

Berdasarkan hasil analisis data dan pembahasan dapat disimpulkan bahwa adanya perbaikan proses pembelajaran dalam upaya meningkatkan kemampuan pemecahan masalah matematis siswa yang dapat ditinjau dari hasil tes kemampuan pemecahan masalah matematis siswa dan lembaran sikap kerjasama siswa dan rasa ingin tahu siswa dan lembaran pengamatan proses pembelajaran pada aktivitas guru dan siswa. Permasalahan-permasalahan realistik yang diberikan selama proses 
pembelajaran memberikan pengaruh secara deskriptif terhadap siswa sehingga siswa dapat menyelesaikan permasalahan dari memahami permasalahan, merancang strategi pemecahan masalah, melakukan perhitungan dan memeriksa kembali hasil yang diberikan.

\section{Saran}

Berdasarkan hasil yang dicapai maka saran yang diajukan adalah sebagai berikut ini. Pertama, pada penerapan PMRI dengan upaya meningkatkan kemampuan pemecahan masalah matematis, sebaiknya peneliti memilih karakteristik siswa yang sesuai. Hal ini disebabkan, tidak semua siswa tertarik dengan pemecahan masalah. Bagi siswa yang punya karakteristik kemampuan rendah, kemampuan pemecahan masalah terlihat tidak tertarik dan siswa hanya diam dan melihat temannya. Namun bagi siswa yang kemampuan menengah ke atas, siswa tersebut terlihat tertarik dengan kemampuan pemecahan masalah matematis. Untuk mengatasi hal tersebut, kerjasama dengan guru mata pelajaran sangat dibutuhkan untuk menentukan karakteristik siswa. Kedua, peningkatan kemampuan pemecahan masalah secara klasikal terlihat meningkat namun hal tersebut masih perlu ditingkat untuk menghasilkan peningkatan yang optimal. Ketiga penerapan PMRI untuk siswa SMP dapat dilakukan dengan baik yang ditinjau dari kemampuan pemecahan masalah matematis siswa.

\section{DAFTAR PUSTAKA}

Arikunto, Suharsimi., Suhardjono \& Supardi. (2010). Penelitian Tindakan Kelas.Jakarta: PT Bumi Aksara

Gravemeijer, K. (1994). Developing Realistic Mathematics Education. Ultrecht: Freudenthal Institute
Hadi, S. (2005). Pendidikan Matematika Realistik. Banjarmasin: Tulip.

Sudjana, N. (2008). Penilaian Hasil Proses Belajar Mengajar. Bandung: Remaja Rodaskarya.

Sugiman \& Kusumah, Y. S. "Dampak Pendidikan Matematika Reaslistik terhadap Peningkatan Kemampuan Pemecahan Masalah Siswa SMP'. IndoMS J.M.E. (Vol 1 No 1). Hlm 42-44.

Van den Heuvel-Panhuizen, M., and Drijvers, P. (2014). Realistic Mathematics Education. S. Lerman (ed), Encyclopedia of Mathematics Education.

Springer

Science+Business Media Dordrecht. DOI 10.1007/978-94-007-4978-8, Hal521-525.

Zulkardi, (2001). Lingkungan belajar RME dan perannya dalam menghasilkan guru RME di indonesia (online). http://www.geocities.com/athens/cre te/2008/01/05. diakses pada tanggal 20 Januari 2013

\section{RIWAYAT HIDUP PENULIS}

Reni Wahyuni, M.Pd. Lahir di

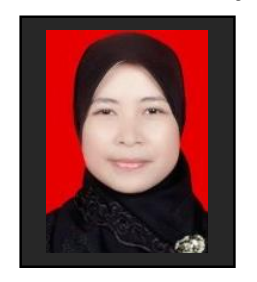

Pekanbaru, Riau 10 Januari 1986. Dosen di Universitas Islam Riau. Studi S1 Pendidikan Matematika Universitas Riau, Pekanbaru, lulus tahun 2008; dan S2 Pendidikan Matematika Universitas Sriwijaya, Palembang, lulus tahun 2011. 